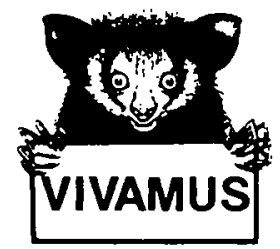

\title{
Tropical Rain Forest Fragmentation and Wild Populations of Primates at Los Tuxtlas, Mexico
}

\author{
Alejandro Estrada ${ }^{1}$ and Rosamond Coates-Estrada ${ }^{1}$ \\ Received March 19, 1996; accepted June 3, 1996
}

In view of the extensive destruction, fragmentation, and conversion of primate habitats to anthropogenic vegetation, information on Neotropical primate ability to use a landscape consisting of forest fragments and agricultural habitats is necessary to understand the ecological flexibility of the species involved and it is of relevance to the design of conservation scenarios at the landscape level. We censused howlers and spider monkeys in 126 forest fragments and in 44 agricultural sites at Los Tuxtlas, southern Veracruz, Mexico, and used the IDRISI Geographic Information System to assess the extent of primate habitat remaining. We conducted economic surveys to assess the productivity of several systems of land management, including cattle ranching. Seventy-five percent of native habitat has been lost at Los Tuxtlas, $20 \%$ remains in the form of isolated fragments of vegetation, and only $5 \%$ consists of contiguous rain forest at high elevations $(>800 \mathrm{~m})$. Howlers and spider monkeys were present in only 60 and $8 \%$ of the forest sites investigated, respectively, attesting to extensive local extinction. Populations of both species are small and found in a fragmented and isolated condition throughout the landscape. A large number of howlers were detected in artifactual habitats such as cacao, coffee and mixed (cacao and coffee) plantations shaded by rain forest trees. Residual rain forest vegetation along streams, rivers, and lakes facilitated the interfragment and interhabitat movement of howlers. Economic surveys showed that some of the agricultural habitats were more productive than cattle ranching. Conservation of spider monkeys requires large areas of contiguous forest, but only small areas are present at high elevations. Howlers are restricted to elevations $<800 \mathrm{~m}$, where most of the forest has disappeared, but can apparently exist in a matrix of forest fragments, arboreal agricultural

\footnotetext{
${ }^{1}$ Estación de Biología "Los Tuxtlas," Instituto de Biología-UNAM, Apartado Postal 176, San Andrés Tuxtla, Veracruz, México.
} 
habitats, and pasture lands. Structural aspects of the vegetation and connectivity among habitat islands may be indispensable components of both landscape scenarios.

KEY WORDS: Alouatta palliata; Ateles geoffroyi; forest fragmentation; primate conservation; Los Tuxtlas, Mexico.

\section{INTRODUCTION}

Faced with rapid and extensive conversion of Neotropical rain forests to a landscape consisting mainly of pasture lands and with the need to preserve the remaining primate wildlife, it is imperative to determine how different species have responded to such anthropogenic alterations of their natural habitats. Reports on how primate species have survived the destruction, fragmentation, and isolation of tropical rain forests and how they are responding to such changes are rare and exist only for few localities in Central and South America (Lovejoy et al., 1986; Garcia-Chiarello, 1993a, b; Galetti et al., 1994). Moreover, data on Neotropical primate ability to use a landscape consisting of forest fragments and agricultural habitats are almost nonexistent [(Bicca-Marques and Calegaro-Marques, 1994) Alouatta caraya in Brazil].

Such information is necessary to understand the ecological flexibility of the species involved, and it is relevant to the design of conservation scenarios that will result in long-term conservation of genetically viable populations of primates in the wild. Rarely answered are basic questions such as What is the approximate size of the population of wild primates that still exist in the landscape of interest? What is the spatial dispersion of the population? Which species have been more affected by the fragmentation of the original habitat? How are primate populations responding to biogeographic variables such as area, isolating distance, and isolating age of the forest fragments they inhabit? How are species responding to the presence of anthropogenic vegetation in the landscape? and What scenarios of land management could help to preserve the remaining primate populations and how compatible are they with the needs of the human populations?

Three species are present in the tropical forests of southern Mexico; one species of spider monkey (Ateles geoffroyi) and two species of howlers (Alouatta palliata and $A$. pigra). In the last five decades, primate habitat destruction in Mexico has resulted in significant contraction of the original geographic distribution of these primates, and today howlers and spider monkeys have become extinct in many parts of southern Mexico. The remaining populations inhabit fragments of rain forest vegetation of variable 
extensions in the southern parts of the country (Estrada and Coates-Estrada, 1988; Watts et al., 1986).

Representatives of Alouatta palliata and Ateles geoffroyi are still present in the region of Los Tuxtlas in southern Veracruz, Mexico, where tropical lowland rain forest, and the primates inhabiting it, reach their northernmost geographic distribution in the continent (Estrada and Coates-Estrada, 1988, 1995). The populations of these species exist in a landscape that has been, as a result of horizontal expansion of pasture lands for cattle ranching, intensively and extensively modified by past human activity (Dirzo and García, 1992; Estrada and Coates-Estrada, 1995). The remaining forests consist of collections of archipelagos of forest fragments varying in size and in isolating distance and age, and some are inhabited by howlers and spider monkeys that live under precarious demographic and ecological conditions (Estrada and Coates-Estrada, 1988; Rodríguez-Luna and Cortes-Ortíz, 1994).

Tropical rain forest destruction and fragmentation result in significant reductions in the size of the original animal populations and in physical and biotic isolation. The latter condition creates an interruption of gene flow, inbreeding depression, truncation of the habitat matrix and intrusion of edges, and a rapid or gradual deterioration of local ecological conditions that render a loss of continued supply of resources, e.g., food and mates (Saunders et al., 1991; Terborgh, 1992). Continued isolation may also result in saturation of the forest remnant by some species, altering intraspecific interactions, in overexploitation of resources, in increased competition and predation, and in changes in fecundity, all leading to significant reductions of the effective population sizes of many species and to a potential collapse of the remaining population (Karr, 1990; Andrén, 1994). Primate species in the wild are not exempt from these effects, and it is thus important that the design of conservation scenarios for wild primate populations in any region consider the remaining habitat islands as functional components of the landscape and not as isolated biotic entities.

With the objective of providing information to contribute to the above, we present results of surveys conducted during 1993-1995 of populations of $A$. palliata and A. geoffroyi in the region of Los Tuxtlas. In addition, we present more detailed information on the responses of the more common of the two primate species, namely, $A$. palliata, to anthropogenic changes in the rain forest landscape. This paper is a complement to earlier publications (Estrada and Coates-Estrada, 1984, 1988) on the results of short- and long-term monitoring of primate habitats and species at Los Tuxtlas. 


\section{METHODS}

At Los Tuxtlas $\left(95^{\circ} 00^{\prime} \mathrm{W}, 18^{\circ} 25^{\prime} \mathrm{N}\right)$ in southern Veracruz, Mexico, tropical rain forest vegetation is present in the form of constellations of forest fragments that vary in size, years of isolation and isolating distance (Fig. 1). In this region the remaining tropical rain forest vegetation is technically known as tall evergreen rain forest (Pennington and Sarukhán, 1968). Mean annual rainfall is $4900 \mathrm{~mm}$, with a drier season $(X=111.7 \pm 11.7$ (SD) mm per month] from March to May and a wetter season $(X=486.25 \pm 87.0$ $\mathrm{mm}$ per month) from June to February, and mean annual temperature is $27^{\circ} \mathrm{C}$ (Estrada $e t$ al., 1985). The altitudinal gradient ranges from sea level to $1600 \mathrm{~m}$ a.s.l., and $70 \%$ of the land is above $300 \mathrm{~m}$ a.s.l (Fig. 1).

\section{Current Distribution of the Tropical Rain Forest in Los Tuxtlas}

We combined, with the aid of the IDRISI Geographic Information System software package (Graduate School of Geography, Clark Univer-

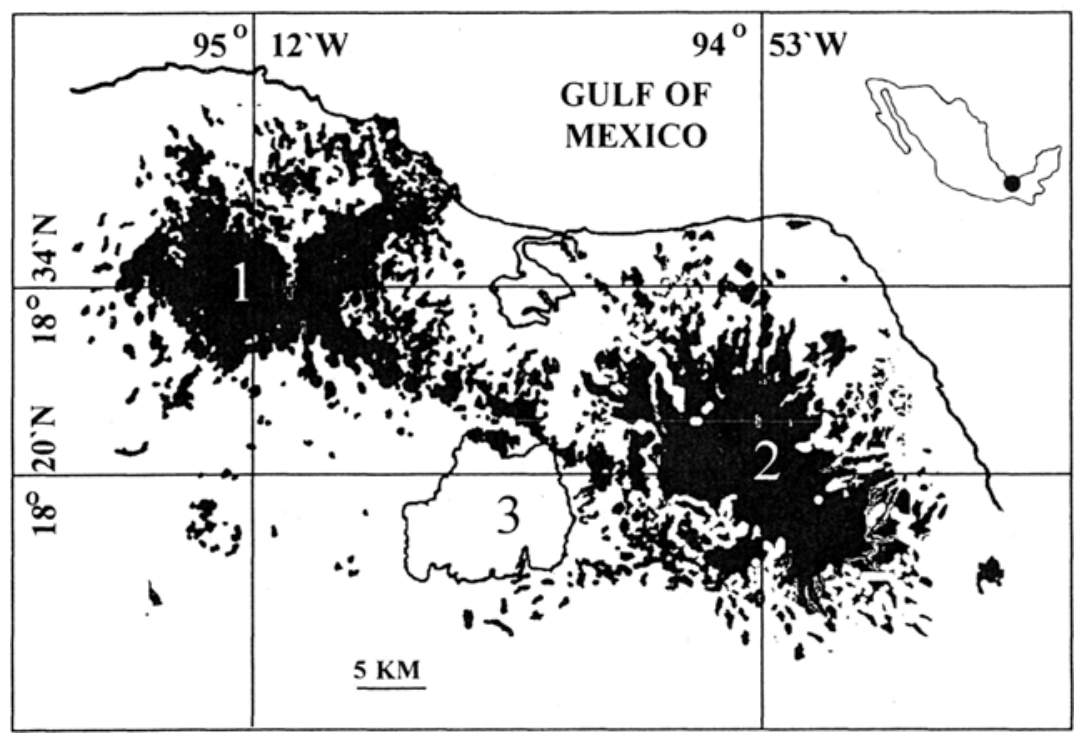

Fig. 1. Region of Los Tuxtlas. Dark areas represent remaining rain forest. 1 and 2 are areas into which the region was divided to assess forest loss along altitudinal gradient. The intersection of coordinates at 1 (Volcan de San Martin Tuxtla) and 2 (Volcan Santa Martha) is highest in elevation, at $1600 \mathrm{~m}$ a.s.l. 3, Lake Catemaco. 
sity), the most recent satellite images (1993) with a topographic map of the region to obtain two types of information. (1) A grid formed by $4 \times$ $4-\mathrm{km}^{2}$ cells was superimposed on the resulting image. Each cell of the grid was in turn divided into $0.5 \mathrm{~km}^{2}$ squares in which we counted the number of $0.5-\mathrm{km}^{2}$ cells occupied by rain forest vegetation. This provided an estimate of the proportion of contiguous rain forest in existence and the proportion of rain forest in a fragmented condition. (2) To estimate the loss of forest along the altitudinal gradient (sea level to $1600 \mathrm{~m}$ ), the region was divided in two areas for examination, one north (Area 1) and the other south (Area 2) of Lake Catemaco (Fig. 1). For each area we used the highest elevations as the intersection of two lines following the cardinal points. Such intersection created four divisions, in each of which we superimposed five grided transects ( $2 \mathrm{~km}$ wide, each cell $=0.5 \mathrm{~km}^{2}$ ), following the altitudinal gradient to sea level. In each of the five transects in each division, we counted the number of $0.5-\mathrm{km}^{2}$ squares cells occupied by rain forest (Fig. 1).

\section{Censuses of Primate Populations}

We censused Ateles and Alouatta in 126 forest fragments dispersed in the region in the two areas indicated above. These sites varied in altitude from sea level to $1600 \mathrm{~m}$, in age of isolation from 1 to 40 years, in size from 2 to $1000 \mathrm{ha}$, and in isolating distance (straight line distance to the edge of the nearest forest fragment) from 0.1 to $8.0 \mathrm{~km}$ (Fig. 1).

We further completed surveys of Alouatta and Ateles in eight replicates of each of the following artifactual habitats: cacao and coffee plantations, mixed plantations (cacao and coffee), and citrus and allspice groves. They varied in size from 2 to 10 ha and in age from 12 to 15 years and were all fruit productive. Distance to the nearest forest patch varied from 200 to $6000 \mathrm{~m}$ and distance to other plantations varied from 200 to $1000 \mathrm{~m}$. In the case of plantations such as cacao, coffee, and mixtures of cacao and coffee, the shade required by the cultivated plants was provided by tall $(>15-\mathrm{m})$ rain forest trees left by the farmers for this purpose.

We accomplished all primate censuses by visual means with the aid of binoculars at all sites and habitats investigated by walking slowly (ca. 1 $\mathrm{km} / \mathrm{hr}$ ) using existing trails or trails opened by us. Their lengths varied with the size of the forest fragment as follows: $400 \mathrm{~m}$ for sites $\leq 50 \mathrm{ha}, 600 \mathrm{~m}$ for sites $\leq 100 \mathrm{ha}, 800 \mathrm{~m}$ for sites $\leq 200 \mathrm{ha}, 1000 \mathrm{~m}$ for sites $\leq 400 \mathrm{ha}, 1500$ $\mathrm{m}$ for sites $\leq 800 \mathrm{ha}, 2000 \mathrm{~m}$ for sites $\leq 1000 \mathrm{ha}$, and $2500 \mathrm{~m}$ for sites $\leq 2000$ ha. 
We selected the routes for these censuses to avoid overlaps from one day to the next and to minimize the probability of observing the same troop or individuals more than once. With each contact we recorded the number of individuals observed, their general age (adults, immatures), and, if adults, their sex. We recorded the height at which they were found and the perpendicular distance to the census trail with the aid of a range finder. We noted the general activity of the troop-traveling, resting, feeding, otherand any special natural body markings such as patches of light hair on the backs, tails, and/or feet of the monkeys to improve identification of the troops observed. We transversed trails twice a day, between 0600 and 1800 hr, on 2 consecutive days at each site.

\section{Census of the Vegetation}

We surveyed the vegetation at each of the sites by recording all trees $\geq 10 \mathrm{~cm}$ in diameter at breast height (dbh) and $\geq 1.5 \mathrm{~m}$ in height in six 10 $\times 10$-m plots. We located the plots randomly within the area where we sampled the primates; the plots were at least $30-40 \mathrm{~m}$ from each other. For each tree, we recorded the species, maximum height, and circumference. We measured vertical foliage density at four randomly selected spots within each of the six plots by scoring vegetation intercepts along a vertical pole at the following intervals: $0-0.5,0.51-1.0,1.1-2,2.1-3,3.1-5,5.1-8,8.1-10$, 10.1-15, and $>15 \mathrm{~m}$ (Schemske and Brokaw, 1981). We expressed intercepts at each height interval as the proportion of total intercepts recorded per site in each habitat. We further measured the height and the dbh of the trees occupied by howlers during the censuses.

\section{Economic Surveys}

We conducted economic surveys in five private ranches and five communal farms-ejidos - to determine the average number of cattle sustained per hectare and the selling price of standing beef. We also monitored revenues from milk production sold to the Nestle company and incorporated these into a gross estimate of the total revenues per hectare per year provided by cattle ranching. In the case of the plantations we interviewed the owners to determine the productivity of the cash crop ( $\mathrm{kg} / \mathrm{ha})$ and monitored the selling prices of the cash crops in the region over 3 years to estimate average eamings grossly on a per hectare per year basis. We calculated the number of man/days invested in the field for each agricultural activity and for cattle ranching from our surveys and interviews. 


\section{Statistical Treatment of the Data}

We use descriptive statistics (mean \pm SD) throughout the paper and computed the Spearman correlation coefficient $\left(r_{\mathrm{s}}\right)$, partial correlation coefficient, and $t$ test for dependent samples when variables and means were compared between groups of data (Fitch, 1992). We expressed foliage vertical diversity via the Shannon-Weaver information index $\left(H^{\prime}\right)$ (Ludwig and Reynolds, 1988) and horizontal plant diversity per habitat as the mean number of tree species censused per site in each habitat. From the primate census data we estimated ecological density for $A$. palliata and for $A$. geoffroyi and we used these figures to estimate the size of the current populations of howlers and spider monkeys in Los Tuxtlas.

\section{RESULTS}

\section{Habitat Loss and Fragmentation}

Our data indicate a considerable reduction of the original extension (ca $2548 \mathrm{~km}^{2}$ ) of the tropical rain forest at Los Tuxtlas. Our estimates of native habitat remaining using the GIS showed that ca. $1922 \mathrm{~km}^{2}(75 \%$ of the total) is without forest, ca. $514 \mathrm{~km}^{2}$ (20\% of total) consists of forest fragments of various sizes, and only ca. $110 \mathrm{~km}^{2}$ (5\% of total) contains contiguous forest at high elevations (Fig. 1). The asymmetrical distribution of forest fragments of different sizes indicates a predominance of forest fragments $<200$ ha in size in the landscape (Fig. 2). Data also show the almost total disappearance of contiguous primate habitat along the altitudinal gradient in the region. Currently, only some sections of the southeastern slope in Area 1 and southwestern slope in Area 2, of the mountain range, show, in some sections, a scattered distribution of forest fragments along the gradient (Figs. 1 and 3).

\section{Total Number of Primates Censused}

Our censuses in 126 forest fragments detected individuals of Alouatta in $60 \%$ of the sites, $40 \%$ were without howlers. In the forest sites with Alouatta, we censused 422 individuals distributed in 60 troops and also detected 20 solitary individuals ( 15 males and 5 females). Mean troop size is 7 (range, 3-14). The mean age and sex composition is 1.9 adult males, 3.3 adult females, 1.3 juveniles ( $>1$ year), and 1.7 infants $(<1$ year) (Appendix Table AI). 


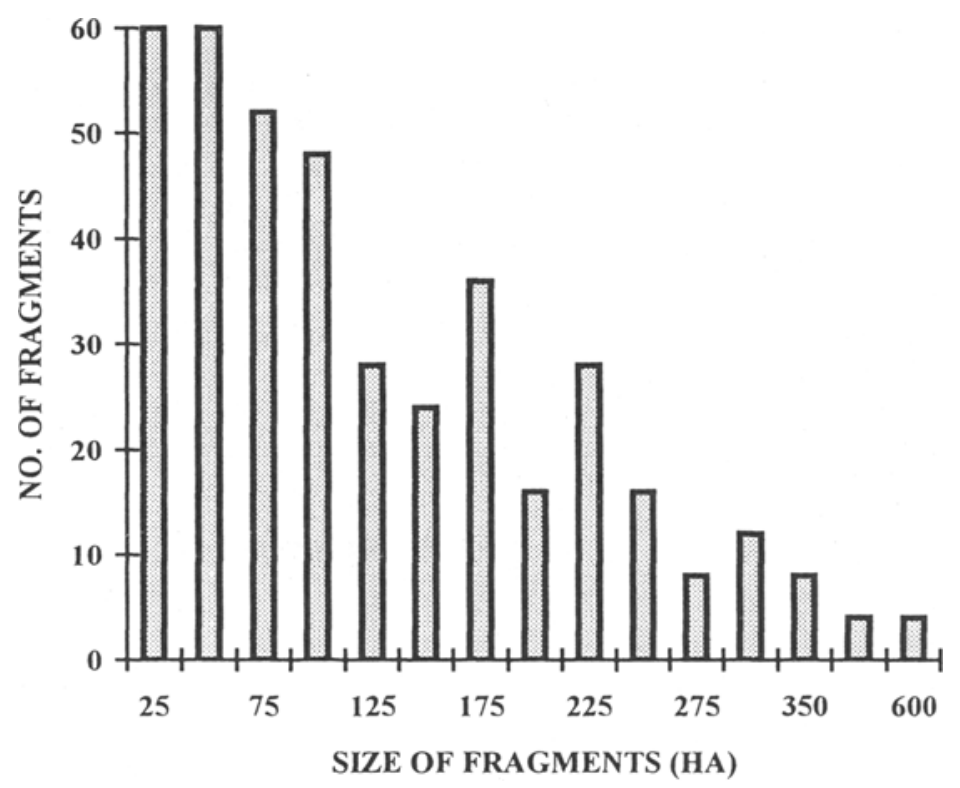

Fig. 2. Size distribution of forest fragments remaining in the region (approximately $514 \mathrm{~km}^{2}$ ).

We detected Ateles in only $8 \%$ of the 126 forest sites investigated. At these sites, we censused 32 spider monkeys. Three of them were solitary animals (two males and one female); the rest were distributed in eight groups. Group size ranged from two to eight individuals, with the following average composition: 1 adult male, 2.1 adult females, 1 juvenile, and 1 infant (Appendix Table AI). We detected individuals of Ateles in only 4 of the 40 agricultural sites, which represent the following artifactual habitats: cacao, coffee, and mixed plantations. We censused 12 Ateles at these sites: 1 was a solitary male, and the rest were distributed in three troops ranging from three to five individuals (Appendix Table AII).

\section{Estimated Size of Populations of Alouatta and Ateles}

Our censuses indicate a gross ecological density for Alouatta of 2.9 individuals per $\mathrm{km}^{2}$ and 0.22 individual per $\mathrm{km}^{2}$ for Ateles. These figures result in an estimated population size for Alouatta of 1500-1800 individuals and of $400-600$ individuals for Ateles. Such populations are found, as 


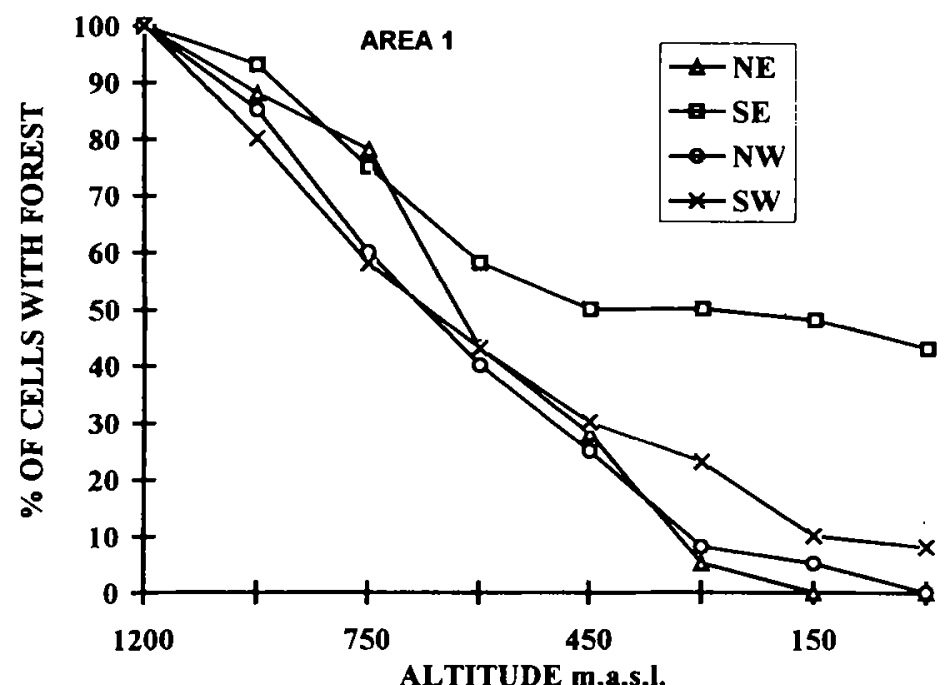

ALTITUDE m.a.s.l.

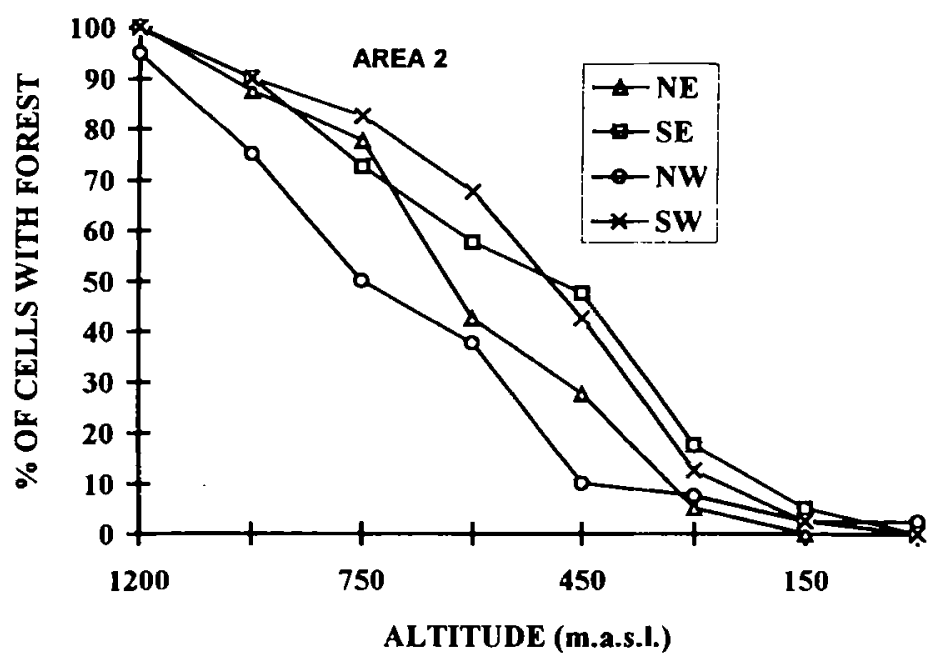

Fig. 3. Distribution of rain forest along the altitudinal gradient in Areas 1 and 2.

their native habitat, in a fragmented and isolated condition in the landscape. 


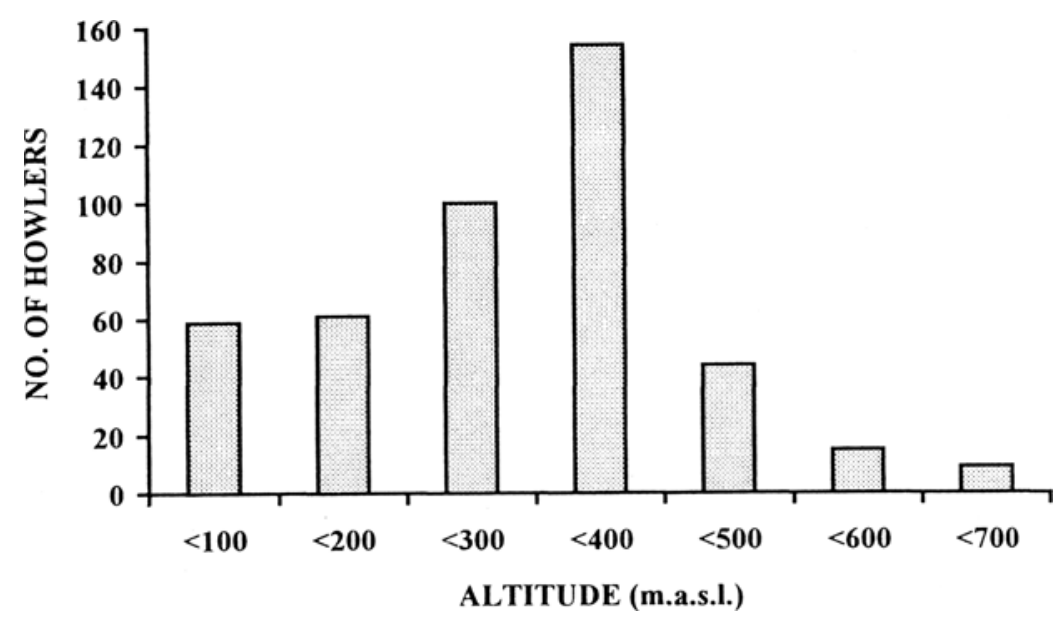

Fig. 4. Distribution of howlers along the altitudinal gradient.

\section{Distribution of Alouatta and Ateles Along the Altitudinal Gradient}

We detected $85 \%$ of the howlers $<500 \mathrm{~m}$ a.s.l. Sixty eight percent of them were in forest fragments at $300-400 \mathrm{~m}$ a.s.l. We detected no howler $>700 \mathrm{~m}$ a.s.l. level (Fig. 4). However, we found spider monkeys in forest fragments ranging in altitude from 100 to $1300 \mathrm{~m}$ a.s.l. (Appendix Table AII).

\section{Effects of Biogeographic Variables on the Population of Alouatta}

The total number of individuals of Alouatta in the forest sites are significantly associated with three biogeographc variables: area $r_{\mathrm{s}}=0.78 P<$ $0.001)$, isolating distance $\left.r_{\mathrm{s}}=-0.45, P<0.001\right)$, and years of isolation $\left(r_{\mathrm{s}}\right.$ $=-0.51 P<0.001$; Fig. 5). Partial correlation analysis showed, however, that of these variables, area correlated best with number of Alouatta $(r=$ $0.76, P<0.001)$, followed by isolating distance $(r=-0.39 P<0.01)$ and age $(r=-0.38 P<0.01)$.

\section{Alowatta in Anthropogenic Vegetation}

We detected individuals of Alouatta in 24 of the 40 focal agricultural sites, which represent three artifactual habitats: cacao, coffee, and mixed 

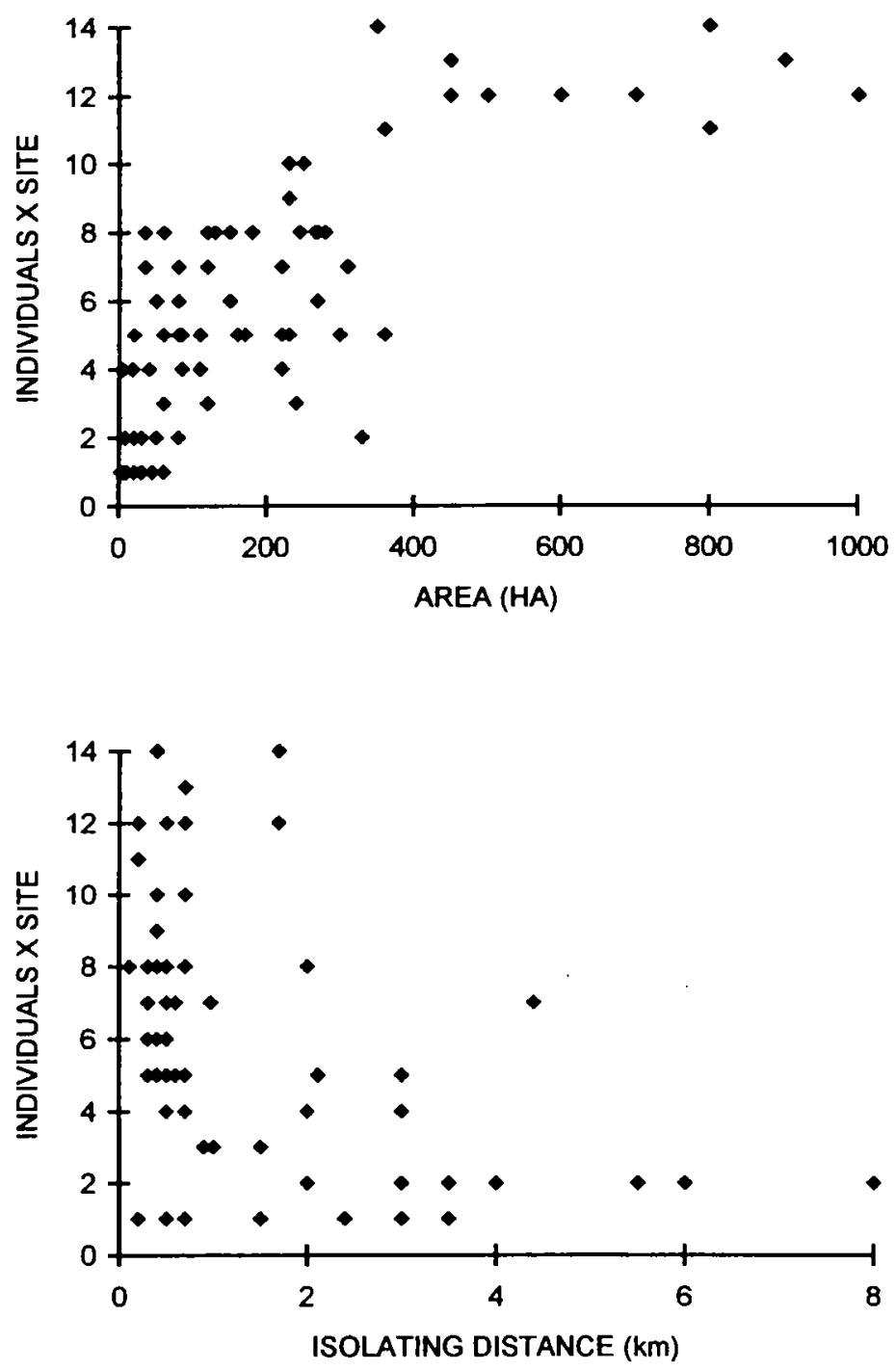

Fig. 5. Relationship between number of individuals of Alouatta detected in our census and biogeographic variables.

plantations (coffee and cacao). At these sites we counted 117 individuals of Alouatta, of which 111 were distributed in 18 troops and the rest were solitary animals ( 4 males and 2 females). Average troop size in these habitats is 6.2 (range, 3-8) and average troop composition is 1.5 adult males, 


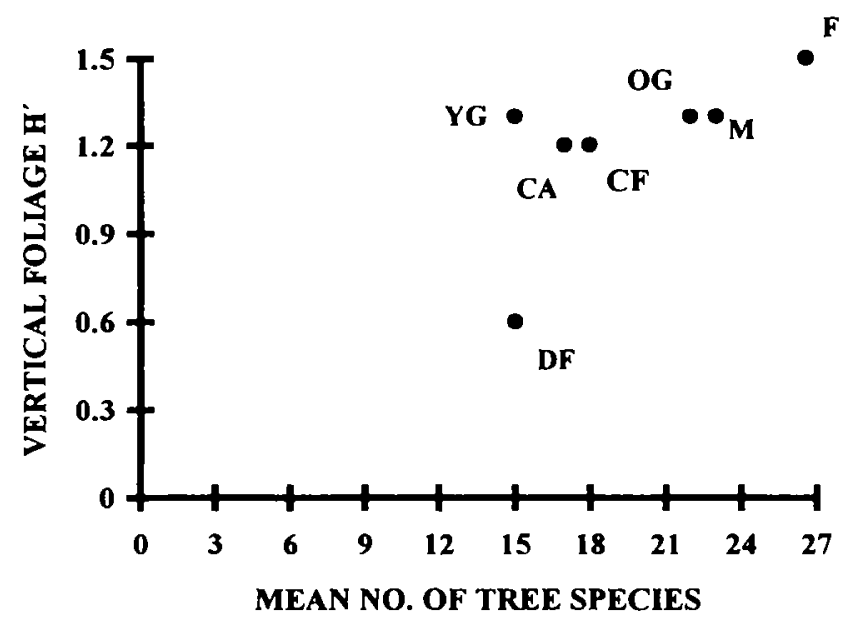

Fig. 6. Relationship between tree species diversity and vertical foliage diversity in the focal habitats. F, undisturbed large forests ( $>100 \mathrm{ha}$ ); DF, disturbed forests ( $<50 \mathrm{ha}$ ), $\mathrm{OG}$, old second growths; YG, young second growths; $C A$, cacao plantation; $C F$, coffee plantation; $M$, mixed plantation (cacao and coffee).

3.1 adult females, 1.2 juveniles, and 1 infant (Appendix Table AIII). Mean troop size is significantly higher at the mixed-crop plantations $7.6( \pm 1.8)$ than at the other two artifactual habitats (cacao, $5.3 \pm 0.8$; coffee, $5.5 \pm$ 1.0; cacao and mixed $t=-3.4$, df $5, P=0.01$; coffee and mixed $t=-4.0$, df $5, P=0.01$ ).

\section{Structure and Diversity of the Vegetation and Size of Populations of Alouatta}

Results of the vegetational censuses at the focal habitats indicate a strong association between horizontal tree diversity and vertical foliage diversity $\left(r_{\mathrm{s}}=0.69, P=0.04\right.$; Fig. 6$)$. Accordingly, the habitats with the highest complexity in the vegetation in these two dimensions are large forest fragments followed by old growths and mixed plantations. Disturbed forest fragments are the least complex according to this measure (Fig. 6). The mean number of individuals of Alouatta censused per site is strongly associated with horizontal plant diversity $\left(r_{\mathrm{s}}=0.98, P=0.02\right)$ and with vertical diversity of the vegetation $\left(r_{\mathrm{s}}=0.76, P=0.0005\right)$. However, partial correlation analysis shows that the only significant effect is that of hori- 


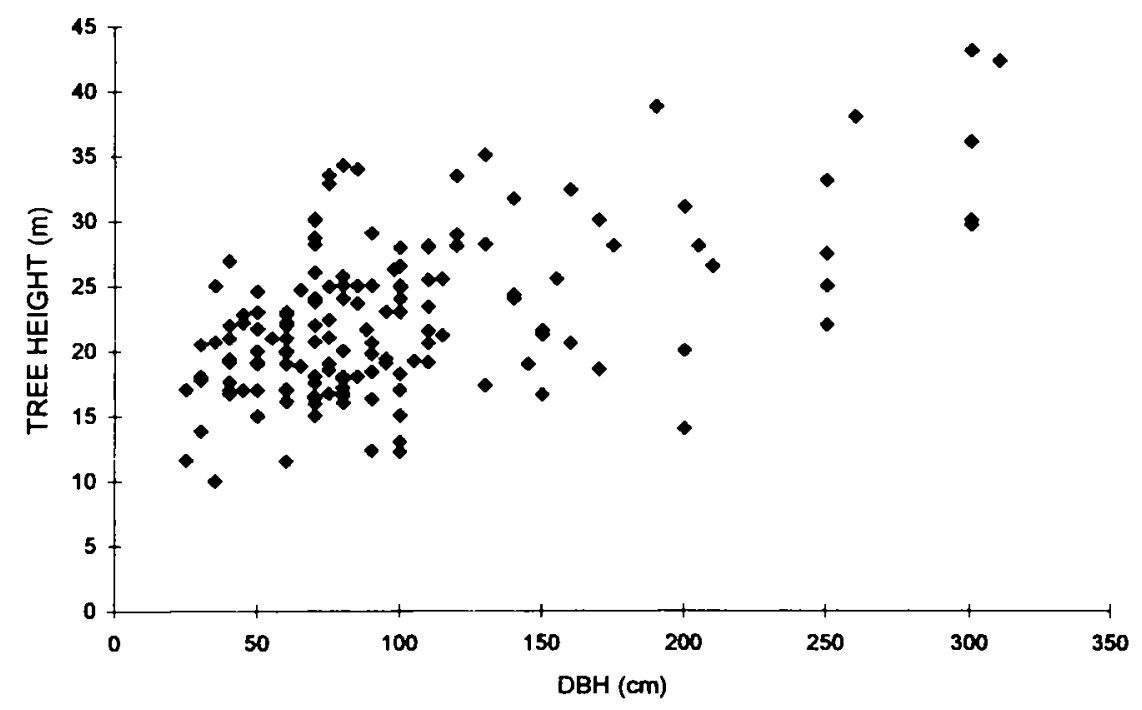

Fig. 7. Relationship between dbh and tree height of trees used by Alouatta at the focal forest sites.

zontal plant diversity $(r=0.83, P=0.009)$. Howlers display a strong preference for large trees as supporting structures in the focal habitats, viz., trees ranging in height from 10 to $43 \mathrm{~m}$ (mean, $22.5 \pm 6.0 \mathrm{~cm}$ ) and in $\mathrm{dbh}$ from 25 to $310 \mathrm{~cm}$ (mean, $98.3 \pm 61.9 \mathrm{~cm}$ ) (Fig. 7).

\section{Economic Value of the Agricultural Habitats Studied}

Our economic surveys indicate that some crops produce higher economic benefits than cattle ranching (Fig. 8). Cacao, allspice and mixed plantations seem to be highly productive options of land management, with an average yield of U.S. $\$ 2,346$ per ha per year. One of the major differences between cattle ranching and these crops is the number of man/days required in the field to produce the crop. For example, the arboreal crops as a group required an average of $62 \mathrm{man} /$ days in the field to operate, with a range of 50 days (citrus) to 75 days (cacao). Contrarily, cattle ranching requires an average of 40 days. Mixed crop plantations, with the highest economic yield per hectare per year, are very labor intensive, requiring about $140 \mathrm{man} /$ days in the field (Fig. 8). 


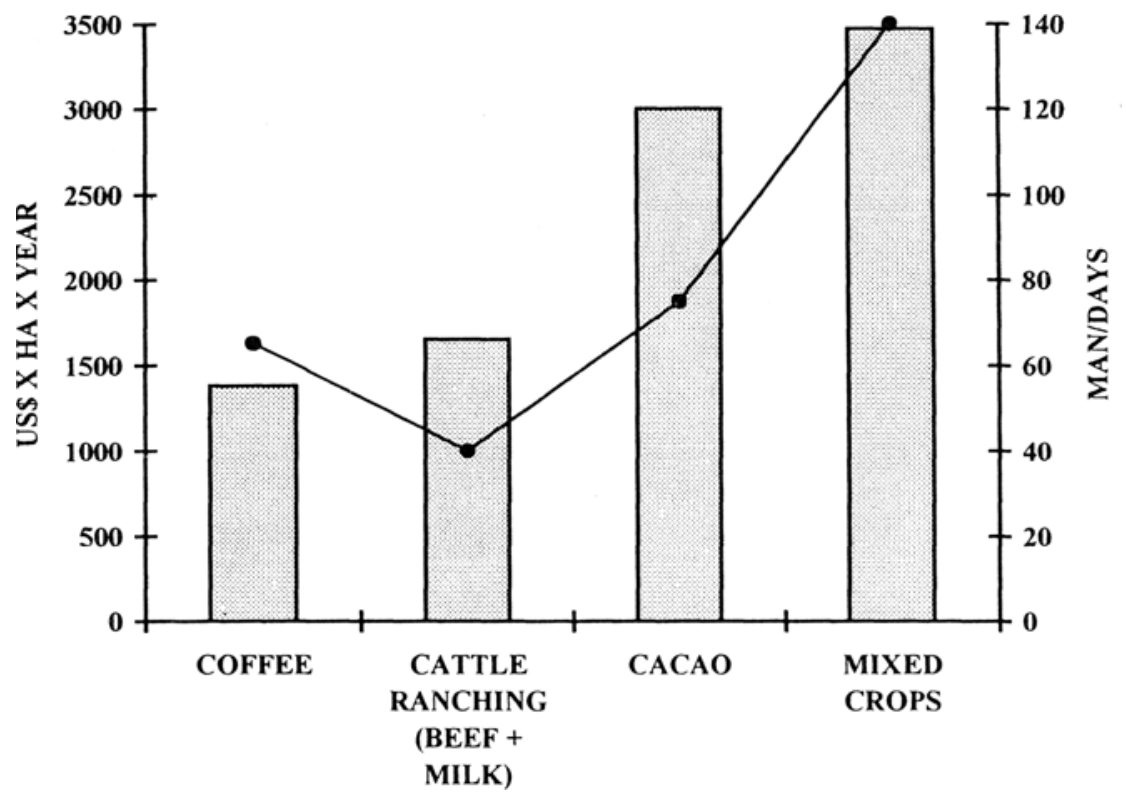

Fig. 8. Economic yield per hectare per year of the focal habitats. Note the higher yield of some cash crops compared to cattle ranching.

\section{DISCUSSION}

Disappearance and fragmentation of the lowland rain forest in Los Tuxtlas have resulted in $80-90 \%$ reduction of area of natural habitat available to Alouatta and Ateles and the trend is continued contraction, fragmentation and isolation of the remaining habitat. Our estimates of population density for Alouatta and Ateles-2.9 individuals per $\mathrm{km}^{2}$ and 0.22 individual per $\mathrm{km}^{2}$ respectively - are lower than those reported earlier (Estrada and Coates-Estrada, 1988) from surveys conducted in the region about 10 years ago (1981-1986)-3.6 individuals per $\mathrm{km}^{2}$ for Alouatta and 0.66 individual per $\mathrm{km}^{2}$ for Ateles)-suggesting important declines in the population as a result of continued isolation of the forest and human activity in the form of further forest removal, selective logging and hunting. This and the fact that Alouatta and Ateles were absent in 40 and $90 \%$ of the focal forest sites, respectively, attest to the extensive local extinction of both species in the region. We estimated that only about $16 \%$ of the original estimated population of $A$ louatta (ca. 10,000 individuals) and about $26 \%$ of Ateles (ca. 1500 individuals) still exist in the region (Estrada and Coates- 
Estrada, 1988). Current populations of Alouatta and Ateles consist of isolated collections of individuals and small groups living in small and large forest islands surrounded by a sea of pasture and other anthropogenic vegetation.

Area and isolating distance of forest fragment seemed to be important variables influencing the number of Alouatta present at a given site. Small area and greater isolation from other forest fragments may result in extensive changes in ecological conditions of the isolated habitat, for example, greater penetration of wind to the interior and higher desiccation at the edges, which may result in a greater mortality of trees, thus diminishing resources for the existing primates (Lovejoy et al., 1986; Laurance, 1991). Our study showed that larger fragments supported larger segments of the divided population of Alouatta, but these fragments are not very common within the altitudinal range occupied by Alouatta at Los Tuxtlas. Short interfragment distances may favor the movement of howlers on the ground through the pasture land from one habitat island to another. We have seen howlers moving on the ground and traveling distances ranging from 10 to $200 \mathrm{~m}$ to reach other forest fragments. However, this has been an infrequently observed behavior, suggesting that there are limits to the distances howlers are willing to travel on the open ground, probably as a result of potential danger from dogs and humans.

Residual rain forest vegetation along the edges of lakes, seasonal and permanent streams, and rivers forming strips of connecting vegetation among isolated forest fragments seems to favor the interfragment movements of primate troops and individuals. We observed more movements of howlers along these corridors than through the open pasture, attesting to the value of such residual vegetation for the primates. The presence and conservation of these corridors of vegetation may sustain connectivity among the isolated segments of the remaining howler population (Noss, 1991; Pimentel et al., 1992; Naiman et al., 1993).

Howler troops and individuals showing an aversion to leave their forest fragment may eventually become extinct because the fragment is too small, it may not contain the necessary resources to support them, its isolation may be so great (large interfragment distance and lack of corridors) that it impedes their temporary and/or permanent self-relocation to other habitat islands (Burkey, 1988; Andrén and Angelstam, 1988), or exposure to predation by humans, dogs, and raptors may be higher at these sites than at larger habitat islands (Estrada, unpublished data). In addition, some of these other habitat islands may be occupied by other howlers, thus exerting more pressure on the limited resources available (Estrada et al., 1994). 
Our surveys indicate that howlers sometimes inhabit anthropogenic vegetation. While a significant number of monkeys were present in the arboreal agricultural habitats, not all of these habitats are equal in the opportunities they may offer to them. For example, shaded habitats were the only artifactual habitats with howlers, probably the result of the presence of rain forest trees. Unshaded agricultural habitats-citrus and allspice-lack tall plant cover, which coupled with the wide interrow space between the cultivated plants and the sparse vegetation, means a lack of suitable structures for primate locomotion, protective cover, and food resources, and thus howlers do not seem to visit these habitats.

The presence at the shaded agricultural habitats used by howlers of tall $(>20-\mathrm{m})$ rain forest trees of plant families such as Moraceae (Ficus spp., Poulsenia armata, Brosimum alicastrum), Leguminosae (Pterocarpus rorhii, Lonchocarpus guatemalensis), Sapotaceae (Manilkara zapota, Pouteria campechiana), Anacardiaceae (Spondias radlkoferi), Lauraceae (Nectandra ambigens, Ocotea spp.), and Annonaceae (Rollinia jimenezii) among others, permits the existence of a contiguous canopy for these mobile arboreal mammals. Some of these tree species are also an important source of leaves and of fruit for the monkeys (Estrada, 1984; Estrada and Coates-Estrada, 1993).

The tall plant cover provided by the rain forest trees at these plantations coupled with the high tree diversity in the vegetation providing shade to the cultivated plants and the absence of hunting of howlers in these habitats by local humans has allowed the persistence of isolated troops of howlers and may also explain the high mean troop size detected at these habitats. In some instances, we observed troops and solitary animals visiting cacao, coffee, and mixed plantations by moving through the trees of narrow strips of forest vegetation along streams and rivers. In some cases, the troops were present with other troops at these plantations.

Our observations and interviews with the farmers indicate that howlers do not feed on the economically important fruits but, instead, concentrate their feeding on leaves and fruits of the tall rain forest trees. The feeding activities of howlers at these habitats may favor primary productivity in artifactual habitats, accelerating the flow of nutrients and the conversion of matter and energy (Estrada and Coates-Estrada, 1993). Likewise, the ingestion of fruits may favor the dispersal of rain forest seeds to less competitive sites for their establishment, contributing thus to sustaining the arboreal species present at the plantations, which could also be managed by people (Estrada and Coates-Estrada, 1984, 1986). The movement of seeds may be enhanced by the use of corridors of residual vegetation by the monkeys when moving from a forest fragment to an artifactual habitat, and vice versa (Estrada et al., 1993). 
Although $<3 \%$ of the land at Los Tuxtlas is dedicated to the cultivation of arboreal crops under the shade of rain forest canopy trees and most of the time such plantations are virtual islands of vegetation surrounded by pastures, the few occurrences investigated may allow us to contemplate scenarios of land management that could be more benign for the conservation of the remaining primate populations (Estrada and Coates-Estrada, 1995). In this case, a landscape arrangement in which arboreal and shaded agricultural habitats occupy some of the pasture separating archipelagos of forest fragments, including forests in process of regeneration, may reduce isolating distances, thereby facilitating the flow of primates through space. In some instances the agricultural plots could be used to protect the edges of forest fragments from exposure to wind and high temperatures and to increase the area of vegetation available to howlers. In this scenario, corridors of residual forest vegetation along streams and rivers could enhance faunal connection between forest and agricultural islands in the landscape. Such management of the land may have several important added benefits including retention of soil and of soil fertility and preservation of water resources (Gleissman et al., 1981; Morowitz, 1991; Orr, 1991).

We also need to consider that Alouatta and Ateles may not be equally elastic in their response to environmental change. For example, we still lack sufficient knowledge about the capacity of spider monkeys to use anthropogenic habitats such as the coffee, cacao and mixed plantations. We detected very few spider monkeys at these habitats. In the case of Alouatta, their presence at these habitats may be facilitated by the capacity of the species to eat the leaves of the rain forest trees providing shade to the cultivated plants. In extreme conditions of humar habitat modification, isolated troops of howlers have used the leaves and fruits of cultivated plants such as Citrus spp. (Bicca-Marques and Calegaro-Marques, 1994). In the case of Ateles, its high dependence on ripe fruit as a principal item in its diet imposes larger demands of area and resources (Mittermeier and van Roosmalen, 1981). Thus while a troop of Alouatta composed of 10 individuals can exist for several years without apparent problems in a 10-ha mixed plantation (Estrada, unpublished data), shaded by rain forest vegetation, an equivalent biomass of spider monkeys would require 100 times that area (Chapman, 1988).

Thus the conservation of Ateles in regions such as Los Tuxtlas may depend on the conservation of large tracts of rain forest in which genetically viable populations can be preserved (Shaffer, 1987). A gross estimate (2.5$5.0 \mathrm{~km}^{2}$ per 10 individuals) of the area required in this case would be $250-500 \mathrm{~km}^{2}$ for 500 individuals of Ateles. In the case of Alouatta, the gross estimate yields $\left(0.3-0.6 \mathrm{~km}^{2}\right.$ per 10 individuals) about $15-20 \mathrm{~km}^{2}$ of con- 
tiguous rain forest. Currently in Los Tuxtlas there is about $624 \mathrm{~km}^{2}$ of rain forest left, but $82 \%$ of it is in an extensive state of fragmentation. Further, most of the forest from sea level to about $700 \mathrm{~m}$ a.s.l. has been lost. This means important changes in the distribution of the two primate species along the gradient.

The fact that $A$. palliata is rarely found above $800 \mathrm{~m}$ a.s.l. in Mexico (Horwich and Johnson, 1986) suggests the presence of certain limitations on the distribution of the species in the mountainous region of Los Tuxtlas. These limitations could be due to specific ecological requirements, colder climate, and/or behavioral restrictions that deter Alouatta from occupying the native vegetation found at higher altitudes. This means that, at Los Tuxtlas, a significant proportion of the remaining population of Alouatta is seriously at risk because most of the lowland rain forest has disappeared at the elevation where the species is usually found. The persistence of Alouatta under this scenario may be due to its ability to use leaves as food, thus existing, for a time, in very small habitat islands or, on occasion, in some artifactual habitats. In contrast, Ateles can occupy higher elevations in the distribution of variants of the rain forest vegetation along the altitudinal gradient of Los Tuxtlas, but as a result of its large area requirements and exploitation of patchy resources, it has been much more sensitive than Alouatta to the general disappearance of its habitat and cannot persist in small patches of vegetation. This, plus intensive hunting by humans over several decades has resulted in dramatic declines of spider monkey population (Estrada and Coates-Estrada, 1988).

In the case of Los Tuxtlas, we need to recognize that the natural habitat of both primate species is now, along several ecological and geographical dimensions, a limited resource and that continued isolation may result in further decreases in the remaining howler and spider monkey populations. This suggests the indispensableness of treating the problem of primate conservation at the level of the landscape. For example, in the case of Alouatta, a combination of archipelagos of forest fragments in combination with some types of agricultural habitats may be useful to preserve the remaining population-variegated models (McIntyre and Barret, 1992). In the case of Ateles, it would be indispensable to ensure the preservation of the largest tracts of rain forest still existing in the region. In both cases, the preservation and use of residual vegetation along streams, rivers, lakes, and lagoons would be necessary to ensure and to enhance physical and biotic connectivity. In this scenario we also may need to consider architectural aspects of the vegetation in such cor- 
ridors. For example, our data suggest that small-low-height and small$\mathrm{dbh}$-trees may not be adequate to facilitate the movements of howlers through the canopy.

Our economic surveys show that, in contrast to cattle ranching, the cultivation of some of the crops may be a more economically productive mode to manage tropical land. Such management of the land, in addition to being less sensitive to fluctuations in the market value of the different cash crops involved, may have several important added benefits, among which stand out retention of soil and of soil fertility and preservation of water resources (Gleissman et al., 1981). The chief obstacle to a change of land management strategy may be economic. First, the crops investigated are, in contrast to pastures, labor intensive and resources would be required to hire the extra human labor. Second, crops such as cacao and coffee require technology, e.g., propane dryers to dry the seeds, to reach high productivity levels for processing before they can be marketed. Although only a few farmers at Los Tuxtlas have had enough resources to cultivate crops with a high market value and have diversified their private economies, we recommend a change in this direction, rather than to continue with the horizontal expansion of cattle ranching, which could result in greater economic benefits to the local economies.

Finally, as conservational primatologists we need to reconsider the problem of primate conservation not just from a basic ecological viewpoint but, instead, as a multidimensional social problem. This scenario demands the development of interdisciplinary research projects that can tackle the problem at different levels. One would be projects that could contribute to increased productivity of the pasturelands to diminish pressure on the remaining primate habitats. Thus, for example, we may need to investigate how to improve bovine genetics via introduction of different breeds of cattle or artificial insemination, to change the types of planted grass species for cattle grazing, to introduce rotating and strip grazing and cultivation of forages, and to improve preventive veterinary care (Herr and Reed, 1991; Bennett, 1995; Cassell 1995). Unless radically different models of land management that involve recent progress in agroforestry and veterinary science are implemented in tropical regions such as Los Tuxtlas, the continued growth of traditional cattle ranching through horizontal expansion of pasture lands, at the expense of the remaining forest, will continue to cause the local and regional extinction of the remnant primate populations, and productivity of the local economies will continue to be insufficient to improve the quality of life of the local human inhabitants. 
APPENDIX

Table AI. Individuals of Alouatta Detected in the Focal Forest Fragments

\begin{tabular}{|c|c|c|c|c|c|c|c|c|c|}
\hline Site & $N$ & Males & Females & Juv. & Inf. & $\begin{array}{l}\text { Altitude } \\
\text { (m a.s.I.) }\end{array}$ & $\mathrm{Ha}$ & $\begin{array}{l}\text { Years of } \\
\text { isolation }\end{array}$ & $\begin{array}{c}\text { Distance } \\
(\mathbf{k m})\end{array}$ \\
\hline 1 & 1 & 1 & & & & 30 & 2 & 12 & 0.5 \\
\hline 2 & 1 & & 1 & & & 40 & 2 & 11 & 0.5 \\
\hline 3 & 1 & 1 & & & & 80 & 2 & 16 & 0.5 \\
\hline 4 & 1 & 1 & & & & 30 & 3 & 15 & 0.7 \\
\hline 5 & 4 & 1 & 2 & & 1 & 100 & 5 & 8 & 0.7 \\
\hline 6 & 1 & 1 & & & & 320 & 8 & 18 & 0.7 \\
\hline 7 & 1 & & 1 & & & 220 & 8 & 15 & 0.7 \\
\hline 8 & 2 & 2 & & & & 320 & 8 & 9 & 8.0 \\
\hline 9 & 1 & & 1 & & & 30 & 10 & 17 & 1.5 \\
\hline 10 & 4 & 1 & 2 & 1 & & 25 & 18 & 20 & 0.5 \\
\hline 11 & 1 & 1 & & & & 30 & 20 & 16 & 3.0 \\
\hline 12 & 2 & 1 & 1 & & & 600 & 20 & 11 & 6.0 \\
\hline 13 & 2 & 1 & 1 & & & 55 & 20 & 14 & 2.0 \\
\hline 14 & 2 & 2 & & & & 140 & 20 & 13 & 3.0 \\
\hline 15 & 5 & 1 & 2 & & 2 & 250 & 20 & 10 & 0.5 \\
\hline 16 & 1 & 1 & & & & 50 & 30 & 14 & 2.4 \\
\hline 17 & 2 & 1 & 1 & & & 70 & 30 & 10 & 5.5 \\
\hline 18 & 7 & 2 & 4 & & 1 & 170 & 35 & 18 & 4.4 \\
\hline 19 & 8 & 3 & 4 & & 1 & 135 & 35 & 13 & 0.5 \\
\hline 20 & 4 & 1 & 3 & & & 35 & 40 & 6 & 2.0 \\
\hline 21 & 1 & & 1 & & & 45 & 45 & 15 & 0.2 \\
\hline 22 & 2 & 1 & 1 & & & 90 & 50 & 9 & 4.0 \\
\hline 23 & 6 & 1 & 3 & 1 & 1 & 180 & 50 & 18 & 0.4 \\
\hline 24 & 1 & & 1 & & & 80 & 60 & 12 & 3.5 \\
\hline 25 & 1 & 1 & & & & 300 & 60 & 11 & 3.5 \\
\hline 26 & 3 & 1 & 2 & & & 20 & 60 & 6 & 1.5 \\
\hline 27 & 5 & 1 & 4 & & & 150 & 60 & 8 & 0.3 \\
\hline 28 & 8 & 2 & 4 & & 2 & 50 & 60 & 15 & 0.3 \\
\hline 29 & 2 & 1 & 1 & & & 60 & 80 & 7 & 3.5 \\
\hline 30 & 2 & 2 & & & & 50 & 80 & 12 & 4.0 \\
\hline 31 & 5 & 2 & 2 & & 1 & 120 & 80 & 18 & 0.4 \\
\hline 32 & 6 & 1 & 3 & 1 & 1 & 380 & 80 & 10 & 0.5 \\
\hline 33 & 7 & 1 & 4 & & 2 & 30 & 80 & 2 & 0.3 \\
\hline 34 & 4 & 2 & 1 & & 1 & 150 & 85 & 15 & 3.0 \\
\hline 35 & 5 & 1 & 2 & & 2 & 25 & 85 & 4 & 0.6 \\
\hline 36 & 4 & 1 & 2 & & 1 & 75 & 110 & 20 & 3.0 \\
\hline 37 & 5 & 2 & 2 & & 1 & 250 & 110 & 4 & 0.7 \\
\hline 38 & 3 & 1 & 2 & & & 400 & 120 & 10 & 1.0 \\
\hline 39 & 7 & 2 & 3 & & 2 & 460 & 120 & 3 & 0.6 \\
\hline 40 & 8 & 2 & 4 & & 2 & 500 & 120 & 10 & 0.5 \\
\hline 41 & 8 & 2 & 3 & 1 & 2 & 250 & 130 & 2 & 0.3 \\
\hline 42 & 6 & 1 & 2 & 1 & 2 & 180 & 150 & 10 & 0.3 \\
\hline 43 & 8 & 2 & 4 & 1 & 1 & 280 & 150 & 2 & 0.1 \\
\hline 44 & 5 & 2 & 3 & & & 450 & 160 & 10 & 0.5 \\
\hline 45 & 5 & 2 & 2 & 1 & & 280 & 170 & 11 & 0.5 \\
\hline 46 & 8 & 3 & 4 & & 1 & 360 & 180 & 8 & 0.5 \\
\hline 47 & 8 & 2 & 4 & & 2 & 220 & 180 & 14 & 0.3 \\
\hline 48 & 4 & 2 & 2 & & & 160 & 220 & 9 & 3.0 \\
\hline 49 & 5 & 1 & 2 & 1 & 1 & 600 & 220 & 17 & 3.0 \\
\hline
\end{tabular}


Table AI. Continued

\begin{tabular}{|c|c|c|c|c|c|c|c|c|c|}
\hline Site & $N$ & Males & Females & Juv. & Inf. & $\begin{array}{l}\text { Altitude } \\
\text { (m a.s.l.) }\end{array}$ & $\mathrm{Ha}$ & $\begin{array}{l}\text { Years of } \\
\text { isolation }\end{array}$ & $\begin{array}{c}\text { Distance } \\
(\mathbf{k m})\end{array}$ \\
\hline 50 & 7 & 2 & 3 & & 2 & 400 & 220 & 11 & 0.5 \\
\hline 51 & 5 & 2 & 3 & & & 260 & 230 & 15 & 3.0 \\
\hline 52 & 9 & 3 & 5 & & 1 & 700 & 230 & 10 & 0.4 \\
\hline 53 & 10 & 3 & 4 & 1 & 2 & 370 & 230 & 12 & 0.7 \\
\hline 54 & 3 & 1 & 2 & & & 246 & 240 & 10 & 0.9 \\
\hline 55 & 8 & 1 & 4 & & 3 & 460 & 245 & 5 & 2.0 \\
\hline 56 & 10 & 2 & 5 & 2 & 1 & 320 & 250 & 7 & 0.4 \\
\hline 57 & 8 & 2 & 3 & 1 & 2 & 360 & 267 & 10 & 2.0 \\
\hline 58 & 6 & 1 & 3 & 1 & 1 & 300 & 270 & 12 & 0.5 \\
\hline 59 & 8 & 2 & 4 & 1 & 1 & 350 & 270 & 10 & 0.7 \\
\hline 60 & 8 & 2 & 3 & 1 & 2 & 180 & 280 & 8 & 0.4 \\
\hline 61 & 5 & 1 & 2 & 1 & 1 & 80 & 300 & 4 & 0.5 \\
\hline 62 & 7 & 2 & 3 & 2 & & 340 & 310 & 15 & 1.0 \\
\hline 63 & 2 & 2 & & & & 140 & 330 & 15 & 2.0 \\
\hline 64 & 14 & 3 & 6 & 2 & 3 & 400 & 350 & 10 & 0.4 \\
\hline 65 & 5 & 1 & 3 & 1 & & 260 & 360 & 15 & 2.1 \\
\hline 66 & 11 & 3 & 5 & 1 & 2 & 270 & 360 & 8 & 0.2 \\
\hline 67 & 12 & 3 & 5 & 2 & 2 & 300 & 450 & 10 & 0.5 \\
\hline 68 & 13 & 3 & 5 & 2 & 3 & 250 & 450 & 9 & 0.7 \\
\hline 69 & 12 & 4 & 5 & 1 & 2 & 350 & 500 & 10 & 0.7 \\
\hline 70 & 12 & 3 & 6 & 2 & 1 & 300 & 700 & 7 & 1.7 \\
\hline 71 & 11 & 3 & 5 & 1 & 2 & 270 & 800 & 6 & 0.2 \\
\hline 72 & 12 & 3 & 5 & 2 & 2 & 300 & 600 & 11 & 0.2 \\
\hline 73 & 12 & 4 & 5 & 1 & 2 & 250 & 700 & 8 & 0.5 \\
\hline 74 & 12 & 3 & 6 & 2 & 1 & 350 & 1000 & 8 & 0.7 \\
\hline 75 & 13 & 3 & 5 & 2 & 3 & 300 & 900 & 6 & 0.7 \\
\hline 76 & 14 & 3 & 6 & 2 & 3 & 350 & 800 & 6 & 1.7 \\
\hline Total & 442 & 129 & 202 & 39 & 72 & & & & \\
\hline
\end{tabular}

Table AII. Number of Spider Monkeys Detected at the Focal Forest Fragments and Artifactual Habitats

\begin{tabular}{|c|c|c|c|c|c|c|c|c|c|c|}
\hline Site & $N$ & Males & Females & Juv. & Inf. & $\begin{array}{l}\text { Altitude } \\
\text { (m a.s.I.) }\end{array}$ & $\mathrm{Ha}$ & $\begin{array}{l}\text { Years of } \\
\text { isolation }\end{array}$ & $\begin{array}{c}\text { Distance } \\
\text { (km) }\end{array}$ & Vegetation \\
\hline 1 & 1 & 1 & & & & 200 & 60 & 30 & 3.0 & Forest \\
\hline 2 & 1 & 1 & & & & 450 & 100 & 20 & 4.0 & Forest \\
\hline 3 & 1 & & 1 & & & 1000 & 600 & 35 & 4.0 & Forest \\
\hline 4 & 2 & 1 & 1 & & & 850 & 300 & 25 & 3.0 & Forest \\
\hline 5 & 3 & 1 & 2 & & & 100 & 270 & 20 & 3.0 & Forest \\
\hline 6 & 3 & 1 & 2 & & & 1300 & 350 & 18 & 1.0 & Forest \\
\hline 7 & 4 & 1 & 2 & & 1 & 900 & 500 & 28 & 0.2 & Forest \\
\hline 8 & 5 & 1 & 2 & 1 & 1 & 1200 & 380 & 30 & 0.3 & Forest \\
\hline 9 & 6 & 1 & 3 & 1 & 1 & 960 & 700 & 35 & 0.8 & Forest \\
\hline 10 & 6 & 1 & 3 & 1 & 1 & 500 & 1000 & 32 & 0.6 & Forest \\
\hline Total & 32 & 9 & 16 & 3 & 4 & & & & & \\
\hline
\end{tabular}


Table AII. Continued

\begin{tabular}{|c|c|c|c|c|c|c|c|c|c|c|}
\hline Site & $N$ & Males & Females & Juv. & Inf. & $\begin{array}{l}\text { Altitude } \\
\text { (m a.s.l.) }\end{array}$ & $\mathbf{H a}$ & $\begin{array}{l}\text { Years of } \\
\text { isolation }\end{array}$ & $\begin{array}{c}\text { Distance } \\
(\mathrm{km})\end{array}$ & Vegetation \\
\hline \multicolumn{11}{|c|}{ Human-made habitats } \\
\hline 1 & 1 & 1 & & & & 400 & 10 & 20 & 0.3 & Cacao \\
\hline 2 & 3 & 1 & 2 & & & 500 & 10 & 25 & 0.5 & Cacao \\
\hline 3 & 5 & 1 & 2 & 1 & 1 & 600 & 8 & 18 & 0.8 & Coffee \\
\hline 4 & 3 & 1 & 2 & & & 400 & 8 & 15 & 0.6 & Mixed \\
\hline Total & 12 & 4 & 6 & 1 & 1 & & & & & \\
\hline
\end{tabular}

Table AIII. Agricultural Sites with Alouatta

\begin{tabular}{|c|c|c|c|c|c|c|c|c|c|c|}
\hline Site & $N$ & Males & Females & Juv. & Inf. & $\begin{array}{l}\text { Altitude } \\
\text { (m a.s.l.) }\end{array}$ & $\mathrm{Ha}$ & Years & $\begin{array}{c}\text { Distance } \\
(\mathrm{km})\end{array}$ & Vegetation \\
\hline 1 & 4 & 1 & 1 & 1 & 1 & 150 & 10 & 25 & 0.3 & Cacao \\
\hline 2 & 6 & 1 & 3 & 1 & 1 & 200 & 10 & 25 & 0.2 & Cacao \\
\hline 3 & 5 & 1 & 3 & & 1 & 250 & 10 & 25 & 0.3 & Cacao \\
\hline 4 & 6 & 1 & 3 & 1 & 1 & 150 & 10 & 25 & 0.3 & Cacao \\
\hline 5 & 6 & 1 & 4 & 1 & 1 & 200 & 10 & 25 & 0.2 & Cacao \\
\hline 6 & 5 & 2 & 3 & & & 250 & 10 & 25 & 0.3 & Cacao \\
\hline 7 & 10 & 3 & 5 & 1 & 1 & 250 & 3 & 15 & 0.2 & Mixed \\
\hline 8 & 8 & 2 & 3 & 2 & 1 & 200 & 3 & 15 & 0.1 & Mixed \\
\hline 9 & 5 & 1 & 3 & & 1 & 50 & 15 & 15 & 0.9 & Mixed \\
\hline 10 & 6 & 2 & 3 & & 1 & 100 & 15 & 15 & 0.4 & Mixed \\
\hline 11 & 8 & 2 & 3 & 2 & 1 & 150 & 15 & 15 & 0.3 & Mixed \\
\hline 12 & 9 & 2 & 4 & 1 & 2 & 200 & 5 & 15 & 0.2 & Mixed \\
\hline 13 & 6 & 2 & 3 & 1 & & 150 & 5 & 5 & 0.6 & Coffee \\
\hline 14 & 6 & 1 & 3 & 1 & 1 & 100 & 5 & 5 & 0.5 & Coffee \\
\hline 15 & 5 & 1 & 3 & & 1 & 200 & 5 & 5 & 0.6 & Coffee \\
\hline 16 & 5 & 1 & 3 & & 1 & 250 & 5 & 5 & 0.4 & Coffee \\
\hline 17 & 7 & 2 & 3 & 1 & 1 & 300 & 5 & 5 & 0.3 & Coffee \\
\hline 18 & 4 & 1 & 2 & 1 & & 350 & 5 & 5 & 0.8 & Coffee \\
\hline Total & 111 & 27 & 55 & 14 & 16 & & & & & \\
\hline \multicolumn{11}{|c|}{ Solitary animals } \\
\hline 19 & 1 & 1 & & & & 80 & 8 & 15 & 0.4 & Cacao \\
\hline 20 & 1 & & 1 & & & 350 & 4 & 18 & 0.6 & Cacao \\
\hline 21 & 1 & 1 & & & & 60 & 5 & 20 & 0.8 & Coffee \\
\hline 22 & 1 & 1 & & & & 40 & 4 & 17 & 0.2 & Coffee \\
\hline 23 & 1 & & 1 & & & 230 & 4 & 20 & 0.3 & Mixed \\
\hline 24 & 1 & 1 & & & & 50 & 2 & 17 & 0.2 & Mixed \\
\hline Total & 6 & 4 & 2 & & & & & & & \\
\hline
\end{tabular}




\section{ACKNOWLEDGMENTS}

We thank the Lincoln Park Zoological Society and its Scott Fund for Neotropical Research for support to launch this research program and for its continued support. The Center for Field Research, Earthwatch, and The Explorers Club of New York provided additional support. Universidad Nacional Autónoma de México provided essential logistical aid.

\section{REFERENCES}

Andrén, H. (1994). Effects of habitat fragmentation on birds and mammals in landscapes with different proportions of suitable habitat: A review. Oikos 71: 355-366.

Andrén, H., and Angelstam, P. (1988). Elevated predation rates as an edge effect in habitat islands: Experimental evidence. Ecology 69: 544-547.

Bennett, M. (1995). Intensive rotational grazing. Jersey J. Oct.: 49-52.

Bicca-Marques, J. L., and Calegaro-Marques, C. (1994). Exotic plant species can serve as staple food sources for wild howler populations. Folia Primatol. 63: 209-211.

Burkey, T. V. (1988). Extinction in nature reserves: the effects of fragmentation and the importance of migration between reserve fragments. Oikos 55: 75-81.

Cassell, B. (1995). Genetic progress is not automatic. Hoard's Dairyman 12: 1127-1128.

Chapman, C. A. (1988). Patterns of foraging and range use by three species of Neotropical primates. Primates 29: 177-194.

Dirzo, R., and Garcia, M. C. (1992). Rates of deforestation in Los Tuxtlas, a neotropical area in southern Mexico. Conserv. Biol. 6: 84-90.

Estrada, A. (1984). Resource use by howler monkeys in the rain forest of Los Tuxtlas, Veracruz, Mexico. Int. J. Primatol. 5: 105-131.

Estrada, A., and Coates-Estrada, R. (1984a). Fruit-eating and seed dispersal by howling monkeys in the tropical rain forest of Los Tuxtlas, Mexico. Am. J. Primatol 6: 77-91.

Estrada, A., and Coates-Estrada, R.(1984b). Some observations on the present distribution and conservation of Alouatta and Ateles in southern Mexico. Am. J. Primatol. 7: 133-137.

Estrada, A., and Coates-Estrada, R.(1986). Frugivory by howling monkeys (Alouatta palliata) at Los Tuxtlas, Mexico: Dispersal and fate of seeds. In Estrada, A., and Fleming T. H. (eds.), Frugivores and Seed Dispersal, W. Junk, The Hague, pp. 93-104.

Estrada, A., and Coates-Estrada, R. (1988). Tropical rain forest conversion and perspectives in the conservation of wild primates (Alouatta and Ateles) in Mexico. Am. J. Primatol. 14: 315-327.

Estrada, A., and Coates-Estrada, R. (1993). Aspects of ecological impact of howling Monkeys (Alouatta palliata) on their habitat: a review. In Estrada, A., Rodriguez-Luna, E., Lopez-Wilchis, R., and Coates-Estrada, R. (eds.), Avances en Estudios Primatologicos en Mexico I, Asociación Mexicana de Primatología, A.C. y Patronatto Pro-Universidad Veracruzana, A.C. Xalapa, Veracruz, Mexico, pp. 87-117.

Estrada, A., and Coates-Estrada, R. (1995). Las Selvas Tropicales Humedas de Mexico: Recurso Poderoso pero Vulnerable, Fondo de Cultura Economica, Mexico.

Estrada, A., Coates-Estrada, R., and Martinez, M. (1985). La Estación de Biología Los Tuxtlas: un recurso para el estudio y conservación de las selvas del trópico húmedo en México. In del Amo, S., and Gomez-Pompa, A. (eds.), Regeneracion de Selvas II, Instituto Nacional de Investigaciones sobre Recursos Bioticos, Editorial Alhambra Mexicana, S.A. de C.V. Mexico, pp. 379-393. 
Estrada, A., Coates-Estrada, R., Merrit, D., Jr., Montiel, S., and Curiel, D. (1993). Patterns of frugivore species richness and abundance in forest islands and in agricultural habitats at Los Tuxtlas, Mexico. In Fleming, T. H., and Estrada, A. (eds.), Frugivores and Seed Dispersal: Ecological and Evolutionary Aspects, Kluwer Academic Group, Dordrecht, The Netherlands, pp. 245-257.

Estrada, A., Coates-Estrada, R., and Meritt, D., Jr. (1994). Non flying mammals and landscape changes in the tropical rain forest region of Los Tuxtlas, Mexico. Ecography.

Fitch, R. (1992). WinSTAT, The Statistics Program for Windows, Kalmia, Cambridge, MA.

Garcia Chiarello, A. (1993a). Activity patterns of the brown howler monkey Alouatta fusca, Geoffroyi 1812, in a forest fragment of Southeastern Brazil. Primates 34: 289-293.

Garcia Chiarello, A. (1993b). Home range of the brown howler monkey (Alouatia fusca) in a forest fragment in southern Brazil. Folia Primatol. 60: 173-175.

Galetti, M., Pedroni, F., and Morellato, L. P. C. (1994). Diet of the brown howler monkey (Alouatta fusca) in a forest fragment in southeastern Brazil. Mammalia 1: 111-118.

Gleissman, S. R., Garcia, R. and Amador, M. (1981). The ecological basis for the application of traditional agriculture technology in the management of tropical ecosystems. Agro-ecosystems 7: 173-185.

Herr, C. M., and Reed, K. C. (1991). Micromanipulation of bovine embryos for sex determination. Theriogenology 35: 45.

Horwich, R., and Johnson, E. D. (1986). Geographic distribution of the black howler (Alouatta pigra) in Central America. Primates 27: 53-62.

Karr, J. R. (1990). Avian survival rates and the extinction process on Barro Colorado Island, Panama. Conserv. Biol. 4: 391-397.

Laurance, W. F. (1991). Edge effects in tropical forest fragments: Applications of a model for the design of nature reserves. Biol Conserv. 57: 205-219.

Lovejoy, T. E., Bierregaard, R. O., Jr., Rylands, A. B., Malcom, J. R., Quintela, C. F., Harper, L. H., Brown, K. S., Powell, A. H., Powell, G. V. N., Schubart, H. O. R., and Hays, M. B. (1986). Edge and other effects of isolation on Amazon forest fragments. In Soule, $M$. E. (ed.), Conservation Biology: The Science of Scarcity and Diversity, Sinauer, Sunderland, MA, pp. 257-285.

Ludwig, J. A., and Reynolds, J. F. (1988). Statistical Ecology, John Wiley and Sons, New York.

McIntyre, S., and Barret, G. W. (1992). Habitat variegation, an alternative to fragmentation. Conserv. Biol. 1: 146-147.

Mittermeier, R. A., and van Roosmalen, M. G. M. (1981). Preliminary observations on habitat utilization and diet in eight Surinam monkeys. Folia Primatol. 36: 1-39.

Morowitz, H. J. (1991). Balancing species preservation and economic considerations. Science 253: $752-754$.

Naiman, R. J., Decamps, H., and Pollock, M. (1993). The role of riparian corridors in maintaining regional biodiversity. Ecol Appl. 3: 209-212.

Noss, R. F. (1991). LanDscape connectivity: Different functions at different scales. In Hudson, W. E. (ed.), Landscape Linkages and Biodiversity, Island Press, Washington, DC, Pp. 110-130.

Orr, D. W. (1991). The economics of conservation. Conserv. Biol. 5: 439-441.

Pennington, T. D., and Sarukhan, J. (1968). Arboles Tropicales de Mexico, Instituto de Investigaciones Forestales, Mexico.

Pimentel, D., Stachow, U., Takacs, D. A., Brubaker, H. W., Dumas, A. R., Meaney, J. J., O'Neil, D., Onsi, E., and Corzilius D. B. (1992). Conserving biological diversity in agricultural/forestry systems. Bioscience 5: 354-362.

Rodriguez-Luna, E., and Cortes-Ortiz, L. (1994). Translocación y seguimiento de un grupo de monos (Alouatta palliata) liberado en una isla (1988-1994). Neotrop. Primates 2: $1-5$.

Saunders, D.A., Hobbs, R. J., and Margulis, C. R. (1991). Biological consequences of ecosystem fragmentation: A review. Conserv. Biol. 5: 18-32.

Schemske, D. W., and Brokaw, N. (1981). Treefalls and the distribution of understory birds in a tropical forest. Ecology 62: 938-945. 
Shaffer, M. L. (1987). Minimum viable populations: Coping with uncertainty. In Soule, M. E. (ed.), Viable Populations for Conservation, Cambridge Univ. Press, Cambridge, pp. 69-86. Terborgh, J. (1992). Maintenance of diversity in tropical forests. Biotropica 24: 283-292.

Watts, E. S., Rico-Gray, V., and Chan, C. (1986). Monkeys of the Yucatan Peninsula, Mexico: Preliminary survey of their distribution and status. Primate Conserv. 7: 17-22. 